animals, but to seek veterinary advice in cases of uncertainty; but it does tend to encourage farmers to perform for themselves services which would be more efficiently provided by the veterinary profession.

$$
\text { J. O. L. KrnG }
$$

\section{D'ARCY WENTWORTH THOMPSON}

\section{D'Arcy Wentworth Thompson}

The Scholar-Naturalist, 1860-1948. By Ruth D'Arcy Thompson. Pp. $x i+244+8$ plates. (London: Oxford University Press, 1958.) 25s. net.

A LL of us who knew D'Arcy Thompson personally and the many who made his acquaintance through the pages of "Growth and Form" have reason for gratitude to his eldest daughter for this finely written biography. It brings vividly into memory that majestic figure and ponderous, admirably phrased utterance. There has been, as all must agree, no one like him in the world of zoology, or possibly in that of any other science, in our time.

$\mathrm{He}$ outlived his contemporaries, and most of us who knew him first met him as the author of "Growth and Form" and professor of natural history at St. Andrews, already on the high plateau of the last half of a professorial career that was to extend over sixty-four years. Of how many people would one remember the very first words heard from them ? But there is vivid recollection of the opening phrase in an address he delivered before the Royal Physical Society of Edinburgh some thirty-five years ago. Speaking of Johannes Schmidt and his then recent discovery of the breeding places of the eel, he began, "Aristotle" - a long pause and then again-"Aristotle, who knew a little about everything but not everything about anything ...." and we were launched on an account of modern achievement against a background of classical knowledge.

But, as we learn with so much interest from this 'life', the journey up to the summit of achievement and recognition had been full of disappointments. The chair at Dundee, obtained at the age of twentyfour, was after all a poor alternative to the fellowship at Trinity, Cambridge, that he had hoped for, and there were repeated failures to obtain other chairs or museum directorships. No comparative anatomist, he was out of step with his contemporaries and had he died before the publication of "Growth and Form" (when he was already fifty-seven) he would have had scant attention in any subsequent history of zoology.

His achievements to that date lay primarily in the fields of classical scholarship and of fisheries statistics. Even the two visits to the North Pacific as the United Kingdom representative on the Bering Sea Commission in 1896 and 1897, description of which forms perhaps the most interesting chapter in this book, brought him governmental rather than scientific recognition.

All changed in 1917 after the publication of "Growth and Form", and fame was assured. In this remarkable book his wide knowledge, his mathematical ability and, above all, the wide philosophical outlook which he shared with the Greeks whom he studied and so much admired, find full scope. Supremely well written, it has had a major influence on the direction of biological thought and research, the latter the more surprising because its author was not himself an experimentalist. In a postscript to this biography, Prof. P. B. Medawar contributes a critical essay of high distinction on "Growth and Form".

Perhaps the only criticism concerns the illustrations which could, one feels, have been better chosen. But taken all in all, this is a biography not unworthy of its subject and one that should be widely read and the more treasured as time passes, and with it the memory slowly fades of a great zoologist and a most remarkable personality.

C. M. YoNGE

\section{ALEXANDRE COLLIN-A PIONEER IN SOIL MECHANICS}

Landslides in Clays

By Alexandre Collin, 1846. Translated by W. R. Schriever, with the assistance of J. P. Carrière, R. F. Legget, and D. H. MacDonald; with a Memoir on Alexandre Collin by A. W. Skempton. Pp. xxxvi+ $160+21$ plates. (Toronto: University of Toronto Press; London: Oxford University Press, 1956.) 528. net.

A REFERENCE which appears in all the standard A soil mechanics text-books is to Alexandre Collin's "Recherches Expérimentales sur les Glissements Spontanés des Terrains Argileux" (CarilianGoeury, Paris, 1846). It is a work that has been more quoted than read, and the translation by W. R. Schriever, entitled "Landslides in Clay", is most welcome, for the full text of this work, which is of great historic interest, can now be read by a wide public.

Historically, the work is important to civil engineers, for Collin was much ahead of his time; indeed, nothing approaching the quality of his work was done in soil mechanies for another fifty years. He used the inductive approach, carefully measuring up landslides when they occurred and basing his theories on the considerable amount of field evidence which he had collected. These data are still of value. Others of his contemporaries were deriving mathematical formulæ which bore little relation to the soil to which they were applied.

The analysis of slope stability as carried out to-day is fundamentally that outlined by Collin. He did not, however, attach great importance to this analysis and it is relegated to an appendix in the book.

His description of how he measured the mechanical properties of clay is also very interesting. He demonstrated how clay swells and shrinks with a change in water content, and showed how the shearing resistance also changes. This he measured by applying loads to specimens $4 \mathrm{~cm} . \times 4 \mathrm{~cm}$. in section, producing a double shear failure.

It is difficult to understand why this research was not followed up, and in a memoir on Collin, published with the translation, Prof. A. W. Skempton provides some reasons for it. The memoir is helpful, for it evaluates Collin's work not only in its contemporary setting but also shows where it lies in terms of our present-day knowledge.

Translating such a work cannot have been easy, but the English is extremely readable while yet retaining the feel of a work written in French more than one hundred years ago. To read it is a delightful and instructive recreation. 